Article - Agriculture, Agribusiness and Biotechnology

\title{
Antibacterial Orientale Extracts Against Clavibacter Michiganensis subsp. michiganensis, the Agent of Bacterial Canker of Tomato Disease
}

Jin Cai ${ }^{{ }^{*}}$

https://orcid.org/0000-0003-1597-8143

Yichen $\mathrm{Gao}^{2}$

https://orcid.org/0000-0002-8363-1232

Mengliang Wang ${ }^{1}$

https://orcid.org/0000-0003-1888-6893

Jing Zhang ${ }^{1}$

https://orcid.org/0000-0001-5966-5208

Yongbin Zhang ${ }^{1}$

https://orcid.org/0000-0001-7119-9721

Qi Wang ${ }^{2}$

https://orcid.org/0000-0001-7665-0024

Jiquan Liư

https://orcid.org/0000-0002-4681-6705

${ }^{1}$ Shanxi University, Institute of Applied Chemistry, Taiyuan, Shanxi Province, China; ${ }^{2}$ Shanxi University, School of Life Science, Taiyuan, Shanxi Province, China; ${ }^{3}$ Shanxi University of Chinese Medicine, College of Traditional Chinese Medicine, Yuci, Shanxi Province, China.

Received: 2018.01.16; Accepted: 2019.07.08.

*Correspondence: caijin@sxu.edu.cn; Tel.: +86-351-3586672 (J.C.)

\section{HIGHLIGHTS}

- $\quad$. orientale extracts had a strong antibacterial activity to inhibit $\mathrm{Cmm}$.

- Optimized extraction obtained high levels of antimicrobial substance production.

- Living $\mathrm{Cmm}$ cells from survival rate test had almost no resistance or adaptability.

- Cell membrane and cell wall of $\mathrm{Cmm}$ were the targets of antibacterial action. 
Abstract: Clavibacter michiganensis subsp. michiganensis $(\mathrm{Cmm})$, which is a Gram positive bacterium, causes the bacterial canker of tomato disease. The purpose of the study was to evaluate the antibacterial activity of Polygonum orientale extracts against $\mathrm{Cmm}$. In this study, firstly, effects of three extracting parameters (extractive time, extractive temperature, and solid to liquid ratio) of orthogonal experiment design $\mathrm{L}_{27}\left(3^{13}\right)$ were conducted. Secondly, survival rate was determined and inhibition zone of $\mathrm{Cmm}$ rescued post-stress was monitored. Finally, extracellular $\mathrm{OD}_{260 \mathrm{~nm}}$ value, extracellular protein content, conformational structure of membrane protein, extracellular alkaline phosphatase (AKP) activity, and ATPase activity were measured to investigate the antibacterial mechanism. Results of orthogonal experiment revealed that extractive time and extractive temperature had highly significant $(P<0.01)$ effects on the antibacterial activity of $P$. orientale extracts. The optimum conditions were as follows: $10 \mathrm{~h}$ of extractive time, $60^{\circ} \mathrm{C}$ of extractive temperature, and 1:20 $(\mathrm{g}: \mathrm{mL})$ of solid to liquid ratio. This study also demonstrated that the living cells of each sample from survival rate test had almost no resistance or adaptability, and rescued $\mathrm{Cmm}$ cells were much easier to be inhibited by $P$. orientale extracts. The results of antibacterial mechanism indicated that cell membrane and cell wall of $\mathrm{Cmm}$ were seriously damaged by $P$. orientale extracts, and $P$. orientale extracts reduced the intracellular ATPase activity dramatically. All these findings suggested that $P$. orientale extracts had a strong antibacterial activity to inhibit $\mathrm{Cmm}$, and could be used for the ecological management of the bacterial canker of tomato disease.

Keywords: plant bioactive compounds; antibacterial agent; plant pathogenic bacterium; orthogonal experiment design; biological control.

\section{INTRODUCTION}

Clavibacter michiganensis subsp. michiganensis $(\mathrm{Cmm})$ is the causative agent of bacterial canker of tomato disease [1], an important disease which causes substantial losses in global tomato production areas [2]. Once $\mathrm{Cmm}$ infects tomato, entering through natural openings and wounds, it causes a lot of wilting of leaves, canker of tomato, bird's-eye spots in fruit, and finally death [3,4]. It is difficult to control the bacterial canker of tomato disease. Until now, the main method of controlling $\mathrm{Cmm}$ is using chemical bactericides, such as copper compounds and streptomycin $[5,6]$. However, chemical controls have some serious problems, such as toxic residues, environmental pollution, affecting people's health, and so on [7]. Recently, biological control including using plant extracts has become a useful method for plant disease controlling [8-13].

Polygonum orientale $\mathrm{L}$. is one kind of herbaceous weeds, which is widely distributed in China [14]. As a folk medicine, $P$. orientale has been used for treating coronary heart disease, edema, and diarrhea [14]. Previous studies also showed that the extracts from $P$. orientale had significant effects against Plutella xylostella L., Helicoverpa armigera H., Mythimna separate W., and Mamestra brassicae L. $[15,16]$. To date, there was no report of $P$. orientale extracts against $\mathrm{Cmm}$.

In this paper, we first conducted the orthogonal experiment design $L_{27}\left(3^{13}\right)$ at three controlling factors to optimize the extractive parameters of antibacterial substances from $P$. orientale. Then, we determined the survival rate and monitored the existing time of inhibition zone of $\mathrm{Cmm}$ rescued post-stress, to verify if there is occurrence of $\mathrm{Cmm}$ cells adapted to $P$. orientale extract stress. Thirdly, we investigated the antibacterial mechanism of $P$. orientale extracts against $\mathrm{Cmm}$ by analyzing extracellular $\mathrm{OD}_{260 \mathrm{~nm}}$ value, extracellular protein content, conformational structure of membrane protein, extracellular alkaline phosphatase (AKP) activity, and ATPase activity. 


\section{MATERIALS AND METHODS}

\section{Orthogonal experiment design}

The whole herbs of $P$. orientale were obtained from Fenhe River (Shanxi Province, China) in August 2016. Collected $P$. orientale were air dried and grounded in a blender [17]. The $P$. orientale powder $(5 \mathrm{~g})$ was mixed with ethanol of corresponding volume and was extracted according to the design of $L_{27}\left(3^{13}\right)$ (Table 1 and Table 2). After filtration, each extract was evaporated, and then each dried sample was dissolved in $40 \%$ DMSO to $15 \mathrm{mg} / \mathrm{mL}$.

Table 1. Optimization of antibacterial substance extraction.

\section{Levels Optimization}

\section{Extractive time (A) Extractive temperature (B) Solid to liquid ratio (C)}

\begin{tabular}{llll}
\hline 1 & $6 \mathrm{~h}$ & $40^{\circ} \mathrm{C}$ & $1: 10(\mathrm{~g}: \mathrm{mL})$ \\
2 & $10 \mathrm{~h}$ & $60^{\circ} \mathrm{C}$ & $1: 15(\mathrm{~g}: \mathrm{mL})$ \\
3 & $14 \mathrm{~h}$ & $80^{\circ} \mathrm{C}$ & $1: 20(\mathrm{~g}: \mathrm{mL})$ \\
\hline
\end{tabular}

Antibacterial activity was determined by agar-dilution assay with slightly modified [18-20]. The pathogen $\mathrm{Cmm}$ (cgmcc 1.1909) was obtained from the China General Microbiological Culture Collection Center (Beijing, China). The medium contained $5 \mathrm{~g} / \mathrm{L}$ malt extract, $20 \mathrm{~g} / \mathrm{L}$ agar, $50 \mathrm{mg} / \mathrm{L}$ twain-80, $10 \mathrm{~g} / \mathrm{L}$ peptone, $2 \mathrm{~g} / \mathrm{L}$ beef extract, $1 \mathrm{~g} / \mathrm{L} \mathrm{MgSO}_{4} 7 \mathrm{H}_{2} \mathrm{O}, 5 \mathrm{~g} / \mathrm{L}$ caseinate, $2 \mathrm{~g} / \mathrm{L}$ glycerol, and $5 \mathrm{~g} / \mathrm{L}$ yeast extract, and the $\mathrm{pH}$ was 7.2. $200 \mu \mathrm{L}$ of $\mathrm{Cmm}$ suspension $\left(10^{6} \mathrm{CFU} / \mathrm{mL}\right)$ was spread uniformly on the medium surface. Holes $(10 \mathrm{~mm}$ diameter) were perforated in the medium followed by the addition of $200 \mu \mathrm{L}$ of prepared samples respectively. The control was $40 \%$ DMSO, because $40 \%$ DMSO does not affect $\mathrm{Cmm}$ growth [21]. Samples were cultivated at $28^{\circ} \mathrm{C}$ for $24 \mathrm{~h}$ to allow the diffusions of $P$. orientale extracts into the medium. Then the diameter of inhibition zone was measured to evaluate antibacterial activity. All the experiments were performed in triplicate.

\section{Determination of survival rate and monitoring of inhibition zone of $\mathrm{Cmm}$ rescued post-stress}

Survival rate of $\mathrm{Cmm}$ was determined according to Wu et al. with several modifications [22]. Each liquid medium was added $50 \mu \mathrm{L}$ of $\mathrm{Cmm}$ suspension $\left(10^{6} \mathrm{CFU} / \mathrm{mL}\right)$, and then was added different concentrations of $P$. orientale extracts with two-fold dilution method. For this test, $P$. orientale extracts were dissolved in DMSO, and were added into the medium to obtain the concentration of $0.02 \mathrm{mg} / \mathrm{mL}, 0.04 \mathrm{mg} / \mathrm{mL}, 0.08 \mathrm{mg} / \mathrm{mL}, 0.16 \mathrm{mg} / \mathrm{mL}, 0.31 \mathrm{mg} / \mathrm{mL}, 0.63 \mathrm{mg} / \mathrm{mL}$, $1.25 \mathrm{mg} / \mathrm{mL}, 2.5 \mathrm{mg} / \mathrm{mL}, 5 \mathrm{mg} / \mathrm{mL}, 10 \mathrm{mg} / \mathrm{mL}$ or $20 \mathrm{mg} / \mathrm{mL}$ respectively. In this assay, the total volume of each sample was $50 \mathrm{~mL}$, and the final DMSO concentration was $7 \%(\mathrm{v} / \mathrm{v})$. The sample, which was treated with $7 \%$ DMSO only, was determined as the control. Each sample was incubated in a shaker at $28^{\circ} \mathrm{C}$ for $8 \mathrm{~h}$, and then was stained by methylene-blue. The number of living $\mathrm{Cmm}$ cells $\left(\mathrm{C}_{\mathrm{L}}\right)$ and dead $\mathrm{Cmm}$ cells $\left(\mathrm{C}_{\mathrm{D}}\right)$ were quantified by blood cell counting board under an optical microscope. All the experiments were performed in triplicate. The survival rate was calculated as follow formula:

Survival rate $=\frac{C L}{C L+C D} \times 100 \%$

$\mathrm{C}_{\mathrm{L}}=$ the number of cells, which were colorless.

$C_{D}=$ the number of cells, which presented blue color. 
In order to verify if there is the occurrence of $\mathrm{Cmm}$ cells adapted to $P$. orientale extract stress, following experiments were carried out. The living (remaining) cells of each sample from survival rate test were adjusted to the same concentration and spread on the medium surface. Holes $(10 \mathrm{~mm}$ diameter) were perforated in the medium followed by the addition of $200 \mu \mathrm{L}$ of prepared $P$. orientale extracts $(15 \mathrm{mg} / \mathrm{mL})$. The DMSO $(40 \%)$ was determined as the control. Samples were cultivated at $28^{\circ} \mathrm{C}$ for $24 \mathrm{~h}$, and the diameter of inhibition zone was measured to evaluate antibacterial activity. Then, the existing time of inhibition zone of $\mathrm{Cmm}$ rescued post-stress were recorded from the date of antimicrobial test to the 14th day. When the inhibition zone of $\mathrm{Cmm}$ still existed on the 14th day, we record 14 day in the test. All the experiments were performed in nine times.

\section{Determination of extracellular $O D_{260 \mathrm{~nm}}$ value and extracellular protein content}

Each liquid medium was added $200 \mu \mathrm{L}$ of $\mathrm{Cmm}$ suspension $\left(10^{6} \mathrm{CFU} / \mathrm{mL}\right)$, and then was added different concentrations of $P$. orientale extracts. For this test, $P$. orientale extracts were dissolved in DMSO, and were added into the medium to obtain concentration of $0.06 \mathrm{mg} / \mathrm{mL}$, $0.08 \mathrm{mg} / \mathrm{mL}, 0.10 \mathrm{mg} / \mathrm{mL}$ or $0.12 \mathrm{mg} / \mathrm{mL}$ respectively. In this assay, the total volume of each sample was $200 \mathrm{~mL}$, and the final DMSO concentration was $0.4 \%(\mathrm{v} / \mathrm{v})$. The sample, which was treated with $0.4 \%$ DMSO only, was determined as the control. Then each sample was incubated in a shaker at $28^{\circ} \mathrm{C}$ for $8 \mathrm{~h}$, and the supernatant was obtained by centrifugation at $12000 \mathrm{rpm}$ for 5 minutes. The $\mathrm{OD}_{260 \mathrm{~nm}}$ value of the supernatant was determined by the UV absorption spectrophotometer. The extracellular protein content of the supernatant was determined according to the soluble protein kit (Nanjing Jiancheng Bioengineering Institute; China). All the experiments were performed in triplicate.

\section{Determination of conformational structure of membrane protein}

Each liquid medium was added $200 \mu \mathrm{L}$ of $\mathrm{Cmm}$ suspension $\left(10^{6} \mathrm{CFU} / \mathrm{mL}\right)$, and then was mixed with different concentrations $(0.08 \mathrm{mg} / \mathrm{mL}, 0.10 \mathrm{mg} / \mathrm{mL}$ or $0.12 \mathrm{mg} / \mathrm{mL})$ of $P$. orientale extracts. For this test, $P$. orientale extracts were dissolved in DMSO, and were added into the medium to obtain concentration of $0.08 \mathrm{mg} / \mathrm{mL}, 0.10 \mathrm{mg} / \mathrm{mL}$ or $0.12 \mathrm{mg} / \mathrm{mL}$ respectively. In this assay, the total volume of each sample was $200 \mathrm{~mL}$, and the final DMSO concentration was $0.4 \%$ $(\mathrm{v} / \mathrm{v})$. The sample, which was treated with $0.4 \%$ DMSO only, was determined as the control. The suspensions were incubated at $28^{\circ} \mathrm{C}$ for $8 \mathrm{~h}$, and then were centrifuged at $5000 \mathrm{rpm}$ for 5 minutes. The deposits of each sample were resuspended in sodium chloride $(0.9 \%)$ to adjusting the $\mathrm{OD}_{630 \mathrm{~nm}}$ to 0.3 . The emission spectra of these samples were scanned from $300 \mathrm{~nm}$ to $500 \mathrm{~nm}$ with a fixed excitation wavelength of $280 \mathrm{~nm}$ [23]. The widths of both excitation and emission slit were set to $5 \mathrm{~nm}$ on the F-280 fluorescence spectrophotometer (Tianjin Gangdong Sci \& Tech Development Co. LTD, China). This assay was used to determine the effects of $P$. orientale extracts on the conformational structure of Cmm membrane protein [24,25].

\section{Determination of extracellular AKP activity}

Each liquid medium was added $200 \mu \mathrm{L}$ of $\mathrm{Cmm}$ suspension $\left(10^{6} \mathrm{CFU} / \mathrm{mL}\right)$, and then was added different concentrations of $P$. orientale extracts. For this test, $P$. orientale extracts were dissolved in DMSO, and were added into the medium to obtain concentration of $0.06 \mathrm{mg} / \mathrm{mL}$, $0.08 \mathrm{mg} / \mathrm{mL}, 0.10 \mathrm{mg} / \mathrm{mL}$ or $0.12 \mathrm{mg} / \mathrm{mL}$ respectively. In this assay, the total volume of each sample was $200 \mathrm{~mL}$, and the final DMSO concentration was $0.4 \%(\mathrm{v} / \mathrm{v})$. The sample, which was treated with $0.4 \%$ DMSO only, was determined as the control. Then each sample was incubated in a shaker at $28^{\circ} \mathrm{C}$ for $8 \mathrm{~h}$, and the supernatant was obtained by centrifugation at 12000rpm for 5 minutes. The extracellular AKP activity of the supernatant was determined according to the AKP assay kit (Nanjing Jiancheng Bioengineering Institute; China). All the experiments were performed in triplicate. 


\section{Determination of intracellular ATPase activity}

Intracellular ATPase activity was measured according to $\mathrm{Li}$ et al. with several modifications [26]. For this test, $P$. orientale extracts were dissolved in DMSO, and were added into the medium to obtain concentration of $0.06 \mathrm{mg} / \mathrm{mL}, 0.08 \mathrm{mg} / \mathrm{mL}, 0.10 \mathrm{mg} / \mathrm{mL}$ or $0.12 \mathrm{mg} / \mathrm{mL}$ respectively. In this assay, the total volume of each sample was $200 \mathrm{~mL}$, and the final DMSO concentration was $0.4 \%(\mathrm{v} / \mathrm{v})$. The sample, which was treated with $0.4 \%$ DMSO only, was determined as the control. The suspensions were incubated at $28^{\circ} \mathrm{C}$ for $8 \mathrm{~h}$. Two-milliliter of each sample was centrifuged at 5000rpm for 5 minutes after incubating $8 \mathrm{~h}$. The deposits of each sample were resuspended in $1 \mathrm{~mL}$ sodium chloride $(0.9 \%)$, and then were broken by the sonication method (200w, 15 minutes, $2 \mathrm{~s}$ pulsing, $4 \mathrm{~s}$ intervals). After centrifugation $\left(4^{\circ} \mathrm{C}\right.$, 12000rpm, 8 minutes), the supernatant of each sample was determined as kit instructions (Nanjing Jiancheng Bioengineering Institute, China). All the experiments were performed in triplicate.

\section{Statistics}

Significance (at the $5 \%$ level or at the $1 \%$ level) was analyzed by one-way analysis of variance (ANOVA) using the software (SPSS 17.0).

\section{RESULTS AND DISCUSSION}

\section{Optimization of antibacterial substance extraction}

Orthogonal experimental design is a main method to find out the optimal extractive conditions of antibacterial substance, including extractive time $(\mathrm{h})$, extractive temperature $\left({ }^{\circ} \mathrm{C}\right)$, and solid to liquid ratio $(\mathrm{g}: \mathrm{mL})$ (Table 1) [27]. The advantage of this design is that it can optimize extraction conditions within a limited number of tests [28]. According to $L_{27}\left(3^{13}\right)$, twenty-seven extraction experiments were carried out (Table 2). The results of Table 2 showed that the highest $R$ value was 6.97, and the factor of extractive time was the most dominant effect on antibacterial substance extraction. The levels within three factors were ranked as: A: $2>3>1$; $B: 2>3>1$; C: $3>2>1$ (Figure 1). Analysis of variance (ANOVA) is an objective and statistical decision-making tool for analyzing the differences in experiments [29]. In Table 3, ANOVA was used to analyze the significant factor(s) or interaction(s). Based on ANOVA, extractive time and extractive temperature exert the significant influences on antibacterial substance extraction (Table 3). Solid to liquid ratio, interaction of extractive time and extractive temperature, interaction of extractive temperature and solid to liquid ratio, and interaction of extractive time and solid to liquid ratio do not exert significant influences (Table 3). Accordingly, extractive time and extractive temperature should be paid more attention in industrial extraction. Table 2 showed that the optimal levels of extraction factors were $\mathrm{A}_{2} \mathrm{~B}_{2} \mathrm{C}_{3}$. Thus, $10 \mathrm{~h}$ of extractive time, $60^{\circ} \mathrm{C}$ of extractive temperature, and $1: 20$ (g:mL) of solid to liquid ratio were selected as the optimum extraction conditions. The optimum extraction conditions should satisfy the efficiency of industrial applications [27]. 


\begin{tabular}{|c|c|c|c|c|c|c|c|c|c|c|c|c|c|c|}
\hline \multirow{2}{*}{ Test } & 1 & 2 & 3 & 4 & 5 & 6 & 7 & 8 & 9 & 10 & 11 & 12 & 13 & $\begin{array}{l}\text { Inhibition } \\
\text { zone }(\mathrm{mm})\end{array}$ \\
\hline & A & B & $A \times B$ & $A \times B$ & C & $A \times C$ & $A \times C$ & $B \times C$ & & & $B \times C$ & & & \\
\hline 1 & $1(6 h)$ & $1\left(40^{\circ} \mathrm{C}\right)$ & 1 & 1 & $1(1: 10)$ & 1 & 1 & 1 & 1 & 1 & 1 & 1 & 1 & 10.00 \\
\hline 2 & 1 (6h) & $1\left(40^{\circ} \mathrm{C}\right)$ & 1 & 1 & $2(1: 15)$ & 2 & 2 & 2 & 2 & 2 & 2 & 2 & 2 & 10.00 \\
\hline 3 & 1 (6h) & $1\left(40^{\circ} \mathrm{C}\right)$ & 1 & 1 & $3(1: 20)$ & 3 & 3 & 3 & 3 & 3 & 3 & 3 & 3 & 10.00 \\
\hline 4 & 1 (6h) & $2\left(60^{\circ} \mathrm{C}\right)$ & 2 & 2 & $1(1: 10)$ & 1 & 1 & 2 & 2 & 2 & 3 & 3 & 3 & 17.99 \\
\hline 5 & 1 (6h) & $2\left(60^{\circ} \mathrm{C}\right)$ & 2 & 2 & $2(1: 15)$ & 2 & 2 & 3 & 3 & 3 & 1 & 1 & 1 & 20.85 \\
\hline 6 & 1 (6h) & $2\left(60^{\circ} \mathrm{C}\right)$ & 2 & 2 & $3(1: 20)$ & 3 & 3 & 1 & 1 & 1 & 2 & 2 & 2 & 16.33 \\
\hline 7 & 1 (6h) & $3\left(80^{\circ} \mathrm{C}\right)$ & 3 & 3 & $1(1: 10)$ & 1 & 1 & 3 & 3 & 3 & 2 & 2 & 2 & 13.42 \\
\hline 8 & $1(6 h)$ & $3\left(80^{\circ} \mathrm{C}\right)$ & 3 & 3 & $2(1: 15)$ & 2 & 2 & 1 & 1 & 1 & 3 & 3 & 3 & 15.34 \\
\hline 9 & $1(6 h)$ & $3\left(80^{\circ} \mathrm{C}\right)$ & 3 & 3 & $3(1: 20)$ & 3 & 3 & 2 & 2 & 2 & 1 & 1 & 1 & 21.81 \\
\hline 10 & 2 (10h) & $1\left(40^{\circ} \mathrm{C}\right)$ & 2 & 3 & $1(1: 10)$ & 2 & 3 & 1 & 2 & 3 & 1 & 2 & 3 & 20.35 \\
\hline 11 & 2 (10h) & $1\left(40^{\circ} \mathrm{C}\right)$ & 2 & 3 & $2(1: 15)$ & 3 & 1 & 2 & 3 & 1 & 2 & 3 & 1 & 20.48 \\
\hline 12 & 2 (10h) & $1\left(40^{\circ} \mathrm{C}\right)$ & 2 & 3 & $3(1: 20)$ & 1 & 2 & 3 & 1 & 2 & 3 & 1 & 2 & 22.92 \\
\hline 13 & 2 (10h) & $2\left(60^{\circ} \mathrm{C}\right)$ & 3 & 1 & $1(1: 10)$ & 2 & 3 & 2 & 3 & 1 & 3 & 1 & 2 & 21.54 \\
\hline 14 & 2 (10h) & $2\left(60^{\circ} \mathrm{C}\right)$ & 3 & 1 & $2(1: 15)$ & 3 & 1 & 3 & 1 & 2 & 1 & 2 & 3 & 22.48 \\
\hline 15 & 2 (10h) & $2\left(60^{\circ} \mathrm{C}\right)$ & 3 & 1 & $3(1: 20)$ & 1 & 2 & 1 & 2 & 3 & 2 & 3 & 1 & 24.72 \\
\hline 16 & $2(10 h)$ & $3\left(80^{\circ} \mathrm{C}\right)$ & 1 & 2 & $1(1: 10)$ & 2 & 3 & 3 & 1 & 2 & 2 & 3 & 1 & 20.50 \\
\hline 17 & 2 (10h) & $3\left(80^{\circ} \mathrm{C}\right)$ & 1 & 2 & $2(1: 15)$ & 3 & 1 & 1 & 2 & 3 & 3 & 1 & 2 & 22.67 \\
\hline
\end{tabular}




\begin{tabular}{|c|c|c|c|c|c|c|c|c|c|c|c|c|c|c|}
\hline 18 & $2(10 h)$ & $3\left(80^{\circ} \mathrm{C}\right)$ & 1 & 2 & $3(1: 20)$ & 1 & 2 & 2 & 3 & 1 & 1 & 2 & 3 & 22.75 \\
\hline 19 & $3(14 h)$ & $1\left(40^{\circ} \mathrm{C}\right)$ & 3 & 2 & $1(1: 10)$ & 3 & 2 & 1 & 3 & 2 & 1 & 3 & 2 & 13.58 \\
\hline 20 & $3(14 h)$ & $1\left(40^{\circ} \mathrm{C}\right)$ & 3 & 2 & $2(1: 15)$ & 1 & 3 & 2 & 1 & 3 & 2 & 1 & 3 & 10.33 \\
\hline 21 & $3(14 h)$ & $1\left(40^{\circ} \mathrm{C}\right)$ & 3 & 2 & $3(1: 20)$ & 2 & 1 & 3 & 2 & 1 & 3 & 2 & 1 & 20.85 \\
\hline 22 & $3(14 h)$ & $2\left(60^{\circ} \mathrm{C}\right)$ & 1 & 3 & $1(1: 10)$ & 3 & 2 & 2 & 1 & 3 & 3 & 2 & 1 & 23.75 \\
\hline 23 & $3(14 h)$ & $2\left(60^{\circ} \mathrm{C}\right)$ & 1 & 3 & $2(1: 15)$ & 1 & 3 & 3 & 2 & 1 & 1 & 3 & 2 & 27.55 \\
\hline 24 & $3(14 h)$ & $2\left(60^{\circ} \mathrm{C}\right)$ & 1 & 3 & $3(1: 20)$ & 2 & 1 & 1 & 3 & 2 & 2 & 1 & 3 & 20.97 \\
\hline 25 & $3(14 h)$ & $3\left(80^{\circ} \mathrm{C}\right)$ & 2 & 1 & $1(1: 10)$ & 3 & 2 & 3 & 2 & 1 & 2 & 1 & 3 & 23.00 \\
\hline 26 & $3(14 h)$ & $3\left(80^{\circ} \mathrm{C}\right)$ & 2 & 1 & $2(1: 15)$ & 1 & 3 & 1 & 3 & 2 & 3 & 2 & 1 & 27.75 \\
\hline 27 & $3(14 h)$ & $3\left(80^{\circ} \mathrm{C}\right)$ & 2 & 1 & $3(1: 20)$ & 2 & 1 & 2 & 1 & 3 & 1 & 3 & 2 & 27.67 \\
\hline$K_{1 j}^{a}$ & 15.08 & 15.39 & & & 18.24 & & & & & & & & & $\sum 529.60$ \\
\hline$K_{2 j}$ & 22.05 & 21.80 & & & 19.72 & & & & & & & & & \\
\hline$K_{3 j}$ & 21.72 & 21.66 & & & 20.89 & & & & & & & & & \\
\hline$R^{b}$ & 6.97 & 6.41 & & & 2.65 & & & & & & & & & \\
\hline
\end{tabular}

A, extractive time (h), B, extractive temperature $\left({ }^{\circ} \mathrm{C}\right), \mathrm{C}$, solid to liquid ratio $(\mathrm{g}: \mathrm{mL})$, and " $\mathrm{x}$ ", interaction.

${ }^{a} K_{i j}=(1 / 9) \sum$ indicated antibacterial zone at factor. $j$ indicated factor.

${ }^{\mathrm{b}} R=\max \left\{K_{i j}\right\}-\min \left\{K_{i j}\right\}$, $j$ indicated factor and $i$ indicated level.

The result shown is the mean of three replicates. 


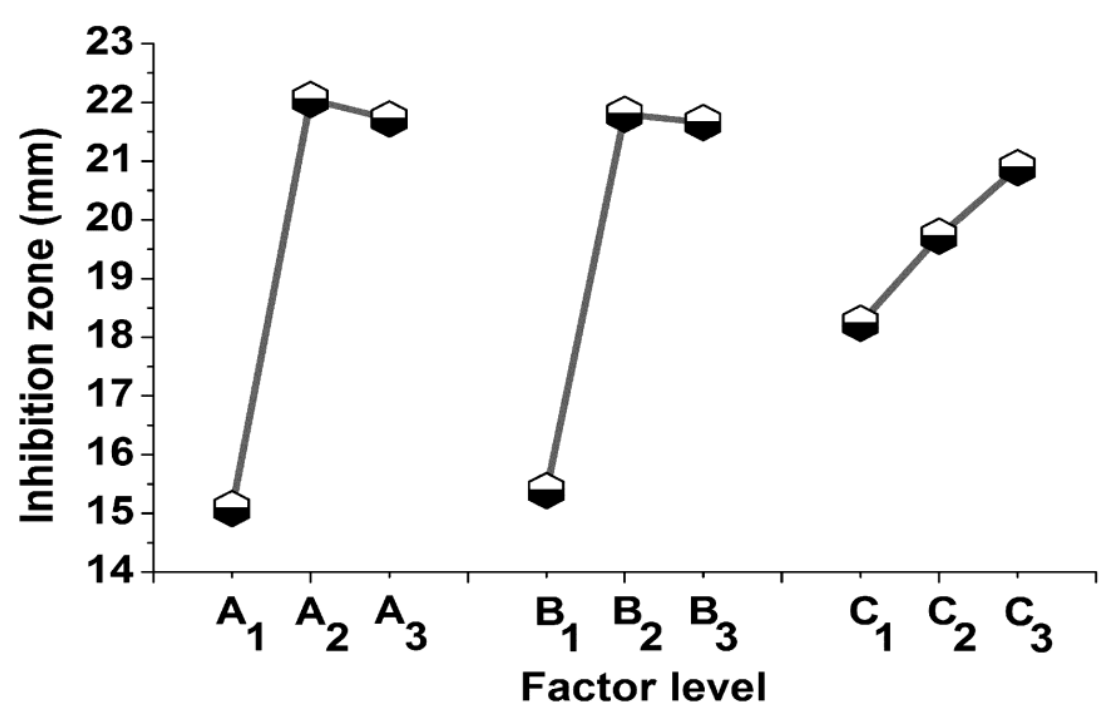

Figure 1. Effect of each factor on antibacterial substance extraction. $A$, extractive time: $A_{1}: 6 h$, $A_{2}: 10 \mathrm{~h}, A_{3}: 14 \mathrm{~h} ; \mathrm{B}$, extractive temperature: $\mathrm{B}_{1}: 40^{\circ} \mathrm{C}, \mathrm{B}_{2}: 60^{\circ} \mathrm{C}, \mathrm{B}_{3}: 80^{\circ} \mathrm{C} ; \mathrm{C}$, solid to liquid ratio: $\mathrm{C}_{1}: 1: 10(\mathrm{~g}: \mathrm{mL}), \mathrm{C}_{2}: 1: 15(\mathrm{~g}: \mathrm{mL}), \mathrm{C}_{3}: 1: 20(\mathrm{~g}: \mathrm{mL})$.

Table 3. Analysis of variance (ANOVA).

\begin{tabular}{llllll}
\hline Source & SS & $\boldsymbol{d f}$ & MS & $\boldsymbol{F}^{\mathbf{a}}$ & Significance $^{\mathbf{b}}$ \\
\hline $\mathrm{A}$ & 277.83 & 2 & 139.92 & 15.92 & ${ }^{* *}$ \\
B & 241.05 & 2 & 120.53 & 13.71 & ${ }^{* *}$ \\
$\mathrm{C}$ & 31.84 & 2 & 15.92 & 1.81 & \\
$\mathrm{~A} \times \mathrm{B}$ & 97.05 & 4 & 24.26 & 2.76 & \\
$\mathrm{~A} \times \mathrm{C}$ & 1.03 & 4 & 0.26 & 0.03 & \\
B×C & 53.34 & 4 & 13.34 & 1.52 & \\
Error & 70.35 & 8 & 8.79 & & \\
Total & 772.49 & 26 & & & \\
\hline
\end{tabular}

A, extractive time (h), B, extractive temperature $\left({ }^{\circ} \mathrm{C}\right), \mathrm{C}$, solid to liquid ratio $(\mathrm{g}: \mathrm{mL})$, and " $\mathrm{x}$ ", interaction. $S S=$ sum of squares; $d f=$ degree of freedom; MS = mean square; $F=$ MSF/MSE (MSF represented the mean square of factors or interactions, and MSE represented the mean square of errors).

a Significant parameter, $F_{0.01}(2,8)=8.65, F_{0.01}(4,8)=7.01$.

$b * *$ indicated more significant different.

\section{Effect of $\boldsymbol{P}$. orientale extracts on survival rate}

Methylene-blue was used to distinguish living and dead bacteria. The viable bacterial had strong reducing power, which could transform methylene-blue from blue to no color. Therefore, the living $\mathrm{Cmm}$ cells were colorless and the dead $\mathrm{Cmm}$ cells presented blue color. Figure $2 \mathrm{~b}$ showed that the numbers of dead bacteria of all treatments were significantly $(P<0.05)$ higher than control. The number of living bacteria (Figure 2 a) and survival rate (Figure $2 \mathrm{c}$ ) showed that when the concentration of $P$. orientale extracts was $0.02 \mathrm{mg} / \mathrm{mL}$, there were no significant differences between control and test group. However when concentration was higher than $0.02 \mathrm{mg} / \mathrm{mL}$, the number of living $\mathrm{Cmm}$ cells and survival rate were significantly 
$(P<0.05)$ decreased. When concentration of $P$. orientale extracts was $20 \mathrm{mg} / \mathrm{mL}$, the survival rate of $\mathrm{Cmm}$ was only $17.10 \%$. These results revealed that $P$. orientale extracts had a strong antibacterial activity against $\mathrm{Cmm}$, and the inhibitory activity had significant concentration effects. 

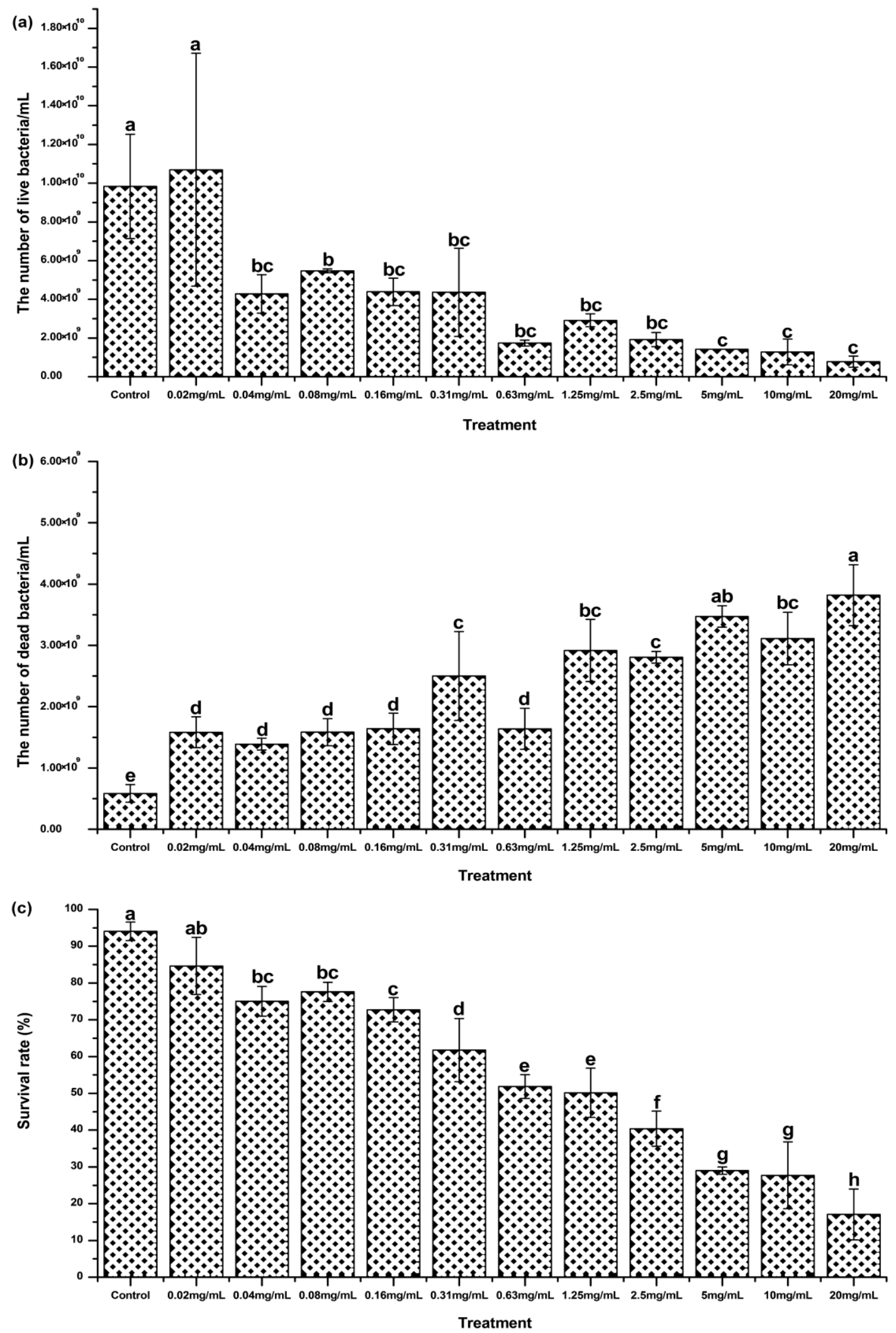

Figure 2. Effect of Polygonum orientale extracts on survival rate of Clavibacter michiganensis subsp. michiganensis $(\mathrm{Cmm})$. (a), the number of living $\mathrm{Cmm}$ cells; (b), the number of dead Cmm cells; (c), survival rate of $\mathrm{Cmm}$ cells. Cmm cells treated with $7 \%$ DMSO were used as the control. Different letters represented significant differences $(P<0.05)$. The result shown is the mean of three replicates. 


\section{Effect of $P$. orientale extracts on inhibition zone of $\mathrm{Cmm}$ rescued post-stress}

The living cells of each sample from survival rate test were used for antibacterial assay to verify if there is the occurrence of $\mathrm{Cmm}$ cells adapted to $P$. orientale extract stress. After 24 hours of cultivation, we tested antibacterial activity with measuring inhibition zone (Figure $3 \mathrm{a}$ ). When the concentration of $P$. orientale extracts in survival rate test ranged from $0.02 \mathrm{mg} / \mathrm{mL}$ to $1.25 \mathrm{mg} / \mathrm{mL}$, there were no significant differences between control and test group. When concentration in survival rate test was higher than $1.25 \mathrm{mg} / \mathrm{mL}$, the antibacterial activity of sample was increased significantly $(P<0.05)$. Then, we observed the inhibition zone from the date of antibacterial test to the 14th day, and recorded the existing time of inhibition zone (Figure $3 \mathrm{~b}$ ). When concentration of $P$. orientale extracts in survival rate test ranged from $0.02 \mathrm{mg} / \mathrm{mL}$ to $5 \mathrm{mg} / \mathrm{mL}$, there were no significant differences between control and test group. When the concentration in survival rate test is higher than $5 \mathrm{mg} / \mathrm{mL}$, the existing time of inhibition zone was increased significantly $(P<0.05)$. These results demonstrated that living cells from survival rate test had almost no resistance or adaptability to $P$. orientale extracts. We speculated that the bioactive compounds of $P$. orientale extracts synergistically inhibited $\mathrm{Cmm}$ from multi-sites, which led to nearly no occurrence of $\mathrm{Cmm}$ cells adapted to $P$. orientale extract stress. Furthermore, the result (Figure 3 ) revealed that when $P$. orientale extract concentration in survival rate test was higher, the antibacterial zone was bigger, and the existing time of inhibition zone was longer. It was proved that the $\mathrm{Cmm}$ cells rescued from $P$. orientale extracts of high concentration were much easier to be inhibited by $P$. orientale extracts. It is probably because that $P$. orientale extracts of high concentration might damage the genetic material of $\mathrm{Cmm}$ dramatically. 
(a)
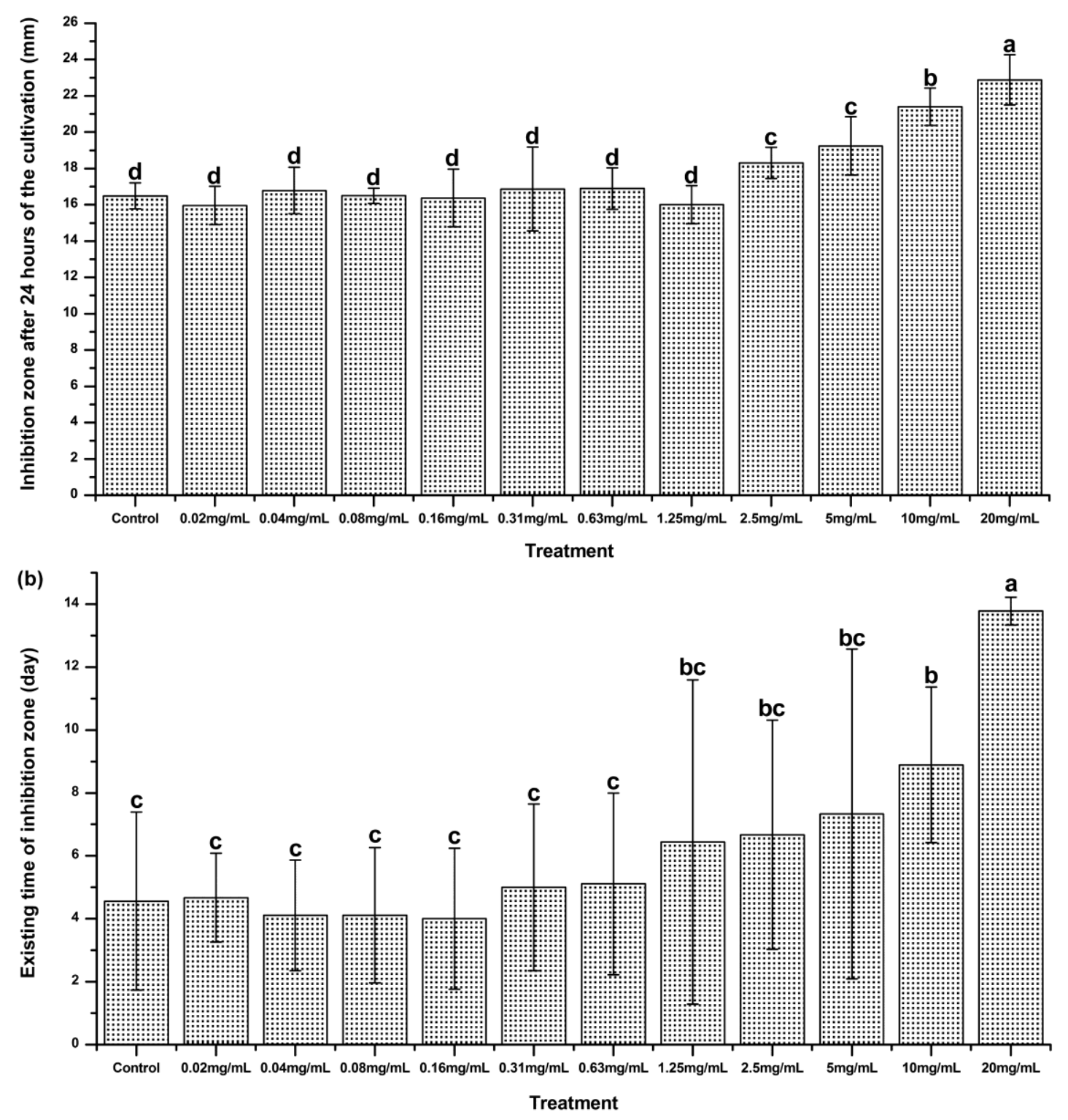

Figure 3. Effect of Polygonum orientale extracts on inhibition zone of Clavibacter michiganensis subsp. michiganensis $(\mathrm{Cmm})$ cells rescued post-stress. (a), the inhibition zone of $\mathrm{Cmm}$ after cultivation for 24 hour; (b), the existing time of inhibition zone of $\mathrm{Cmm}$ rescued post-stress. The DMSO (40\%) was used as the control. When the inhibition zone of $\mathrm{Cmm}$ still existed on the 14th day, we record 14day in the test. Different letters represented significant differences $(P<0.05)$. The result shown is the mean of nine replicates.

\section{Damage to cell membrane of $\mathrm{Cmm}$}

Cell membranes are important functional barriers of bacteria [30]. They play the important roles in information exchange, energy transmission and maintaining intracellular homeostasis [31,32]. When cell membranes of $\mathrm{Cmm}$ are intact, intracellular nucleic acids and intracellular soluble proteins cannot overflow from cells. Only when cell membranes get incomplete can we detect extracellular nucleotides and extracellular proteins [33]. The absorption peak of nucleotide is $260 \mathrm{~nm}$ and therefore we can detect extracellular $\mathrm{OD}_{260 \mathrm{~nm}}$ values to detect extracellular nucleotides. The results of $\mathrm{OD}_{260 \mathrm{~nm}}$ analysis (Figure 4 a) showed that when the 
concentration of $P$. orientale extracts was $0.06 \mathrm{mg} / \mathrm{mL}$, there were no significant differences between control and test group. When the concentration is higher than $0.06 \mathrm{mg} / \mathrm{mL}$, the $\mathrm{OD}_{260 \mathrm{~nm}}$ value of each test group was significantly $(P<0.05)$ higher than control. The results (Figure $4 \mathrm{a}$ ) indicated that when $P$. orientale extracts (greater than or equal to $0.08 \mathrm{mg} / \mathrm{mL}$ ) acted on $\mathrm{Cmm}$ membrane, the nucleotides would leak from cells. In addition, this phenomenon had obvious concentration effects. Proteins are biological macromolecules, which play important roles in bacterial cells. They are involved in almost all of metabolic activities in the cells [34]. The leakage of intracellular proteins can destroy normal physiological activities of bacterial cells. We can also deduce the damaged condition of $\mathrm{Cmm}$ cell membrane from Figure $4 \mathrm{~b}$. When the concentration of $P$. orientale extracts was $0.06 \mathrm{mg} / \mathrm{mL}$ or $0.08 \mathrm{mg} / \mathrm{mL}$, there were no significant differences between control and treatments. When the concentration of $P$. orientale extracts was $0.10 \mathrm{mg} / \mathrm{mL}$ or $0.12 \mathrm{mg} / \mathrm{mL}$, the extracellular protein content of each treatment was significantly $(P<0.05)$ higher than control. The results (Figure $4 \mathrm{~b}$ ) indicated that when $P$. orientale extracts (greater than or equal to $0.10 \mathrm{mg} / \mathrm{mL}$ ) acted on Cmm cells, the intracellular proteins would leak from Cmm cells, and this phenomenon also had obvious concentration effects.

The phenylalanine, tryptophan, and tyrosine residues in protein could emit fluorescence [35]. In most cases, the fluorescence of membrane protein is from tryptophan residues, and changes in fluorescence reflect changes of cell membrane and its surroundings [36]. The effect of $P$. orientale extracts on the fluorescence of membrane protein was showed in Figure $4 \mathrm{c}$. With increase of $P$. orientale extracts, the fluorescence intensity would be increased correspondingly. The results (Figure 4 c) indicated that $P$. orientale extracts could disrupt the native structure of cell membrane or the outside peptidoglycan layer, resulting in the exposure of tryptophan residues in the inner membrane and an increase in fluorescence [37]. 
(a)

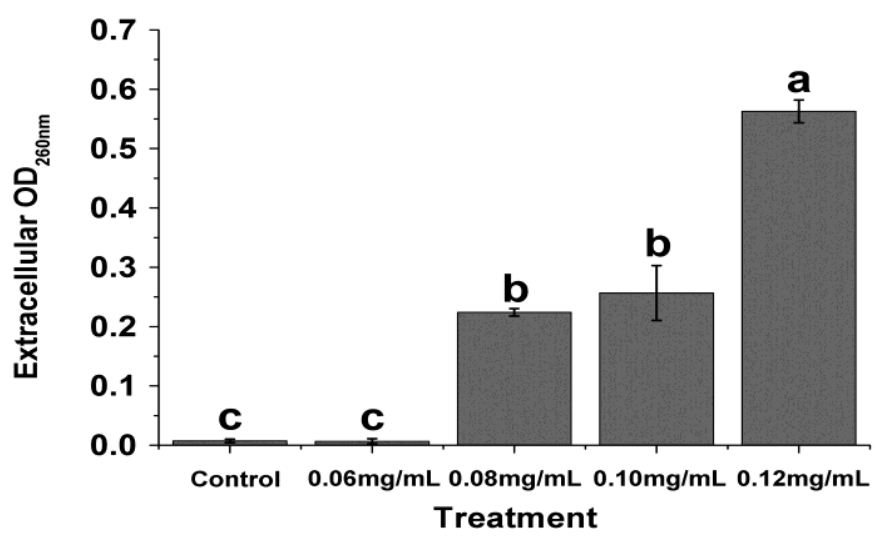

(b)

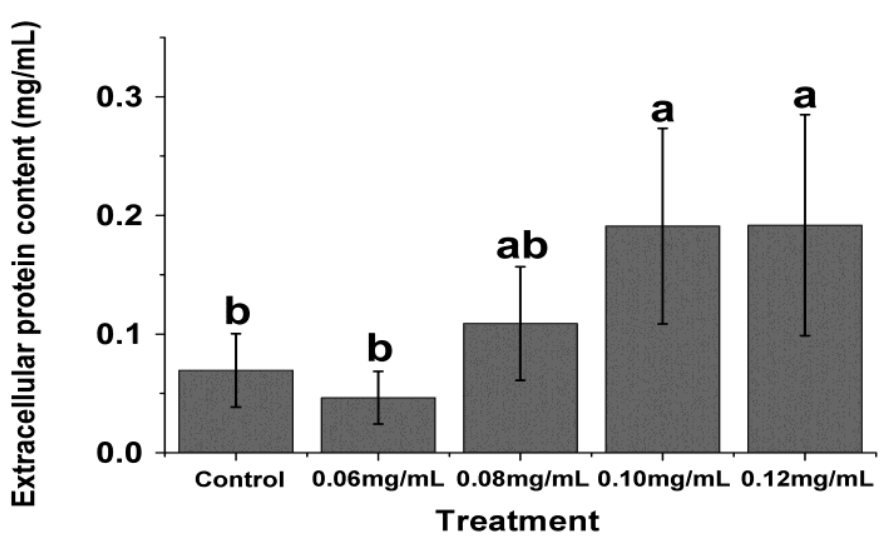

(c)

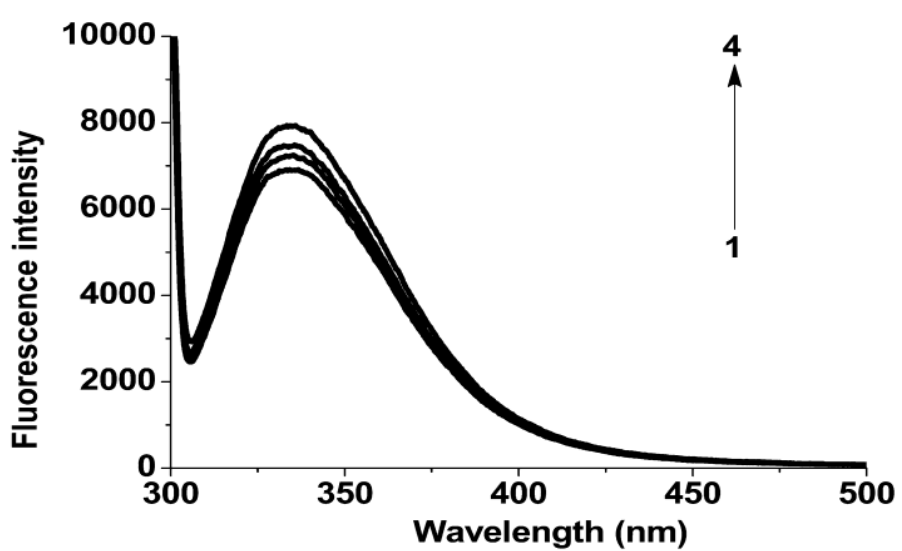

Figure 4. Effect of Polygonum orientale extracts on cell membrane of Clavibacter michiganensis subsp. michiganensis $(\mathrm{Cmm})$. (a), effect of $P$. orientale extracts on extracellular $\mathrm{OD}_{260 \mathrm{~nm}}$ value; (b), effect of $P$. orientale extracts on extracellular protein content; (c), effect of $P$. orientale extracts on the fluorescence intensity of $\mathrm{Cmm}$ membrane protein. $\mathrm{Cmm}$ cells treated with $0.4 \%$ DMSO were used as the control. In Figure 4 (a) and Figure 4 (b), different letters represented significant differences $(P<0.05)$. The result shown is the mean of three replicates. In Figure 4 (c), "1" represented the control; "2" represented Cmm cells treated with $P$. orientale extracts at $0.08 \mathrm{mg} / \mathrm{mL}$; " 3 " represented $\mathrm{Cmm}$ cells treated with $P$. orientale extracts at $0.10 \mathrm{mg} / \mathrm{mL}$; "4" represented Cmm cells treated with $P$. orientale extracts at $0.12 \mathrm{mg} / \mathrm{mL}$.

\section{Damage to cell wall and intracellular ATPase activity}

Bacterial cell walls play important roles in assisting cell movement, transporting materials, and maintaining cell shape. AKP is an enzyme, which is found between cell wall and cell membrane. When cell walls of $\mathrm{Cmm}$ are intact, AKP cannot overflow from cells. Only when cell walls get incomplete can we detect extracellular AKP 
activity [38]. Figure 5 a showed that the extracellular AKP activities of all treatments were significantly $(P<0.05)$ higher than control. This result revealed that $P$. orientale extracts could damage the cell walls of $\mathrm{Cmm}$.

The ATPase is an ATP-driven transporter in bacteria, which can pump hydrogen, calcium, potassium, or sodium ions to produce energy [39,40]. When ATPase transports these ions, some important substances, such as sugars and amino acids, can also enter the cells. Therefore, ATPase plays important roles in a variety of vital biological processes. Figure $5 \mathrm{~b}$ showed that, when the concentrations of $P$. orientale extracts were $0.06 \mathrm{mg} / \mathrm{mL}, 0.08 \mathrm{mg} / \mathrm{mL}, 0.10 \mathrm{mg} / \mathrm{mL}$ and $0.12 \mathrm{mg} / \mathrm{mL}$, the ATPase activity was significantly $(P<0.05)$ lower than control. The results (Figure $5 \mathrm{~b}$ ) revealed that $P$. orientale extracts could damage the intracellular ATPase. We speculated that $P$. orientale extracts damaged the cell membrane of $\mathrm{Cmm}$, resulting in inhibiting ATPase activity in plasma membrane. Furthermore, the decreased ATPase activity should also cause intracellular energy reduction.
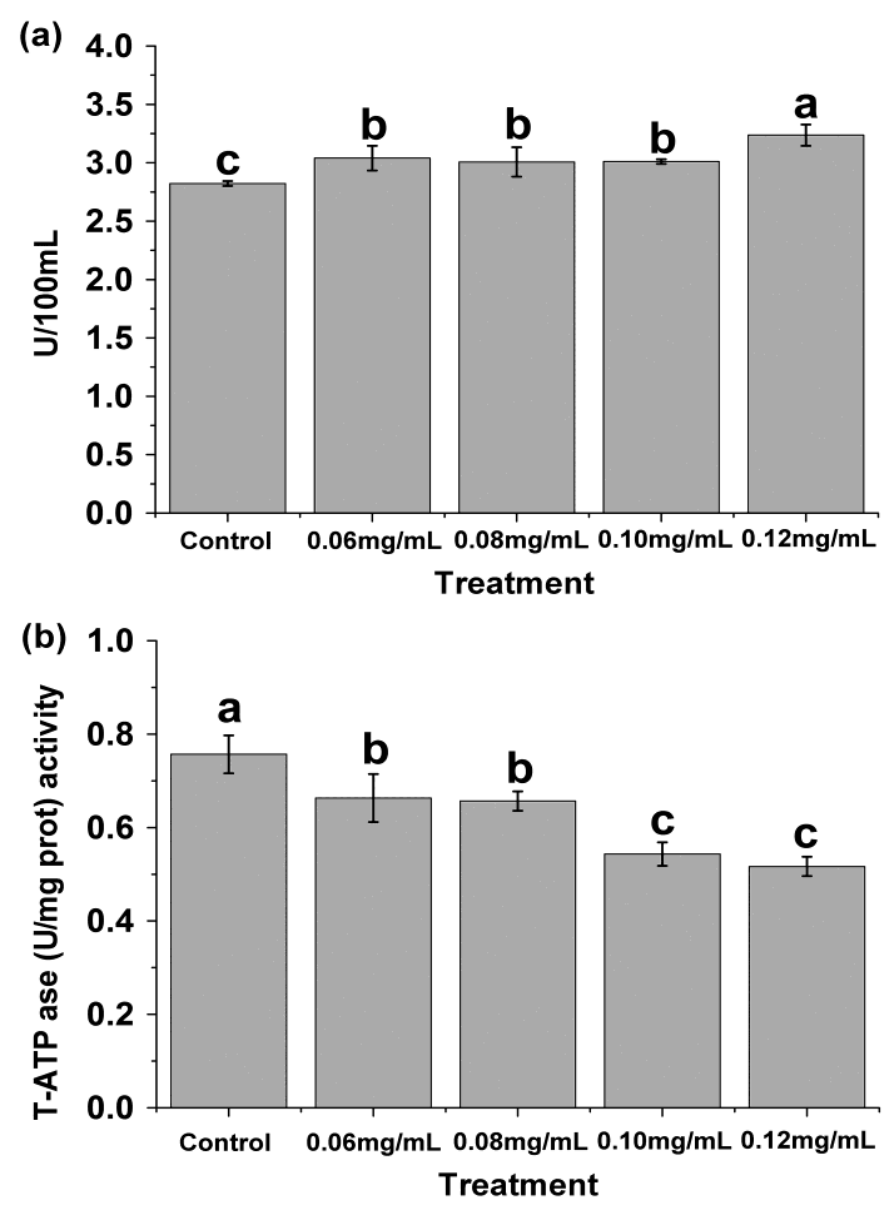

Figure 5. Effect of Polygonum orientale extracts on Clavibacter michiganensis subsp. michiganensis $(\mathrm{Cmm})$ cell physiology. (a), effect of Polygonum orientale extracts on extracellular alkaline phosphatase (AKP); (b), effect of Polygonum orientale extracts on ATPase activity. Cmm cells treated with $0.4 \%$ DMSO were used as the control. Different letters represented significant differences $(P<0.05)$. The result shown is the mean of three replicates.

\section{CONCLUSION}

In conclusion, this work presented a study, which found out the optimized extracting condition of maximum antibacterial activity from $P$. orientale extracts by orthogonal experiment design $L_{27}\left(3^{13}\right)$. The optimal extraction conditions were $A_{2} B_{2} C_{3}$ (extractive time: $10 \mathrm{~h}$; extractive temperature: $60^{\circ} \mathrm{C}$; solid to liquid ratio: $1: 20(\mathrm{~g}: \mathrm{mL})$ ). 
This work also demonstrated that living cells of each sample from survival rate test had almost no resistance or adaptability, and rescued $\mathrm{Cmm}$ cells were much easier to be inhibited by $P$. orientale extracts. Cell membrane is a barrier of bacteria, which can prevent the outflow of internal substances. Hence, we detected extracellular $\mathrm{OD}_{260 \mathrm{~nm}}$ value, extracellular protein content, and the conformational structure of cell membrane protein to indicate the obvious breakage of $\mathrm{Cmm}$ cell membrane. Finally, we demonstrated that $P$. orientale extracts could disrupt cell wall of $\mathrm{Cmm}$ and induce a decrease of intracellular ATPase activity. The results of these assays revealed that $P$. orientale extracts had a strong antibacterial activity against $\mathrm{Cmm}$, and should be used as a botanical bactericide for the management of bacterial canker of tomato disease.

Funding: This research was funded by NATIONAL NATURAL SCIENCE FOUNDATION OF CHINA, grant number 31601677; NATURAL SCIENCE FOUNDATION OF SHANXI PROVINCE, grant numbers 201701D221179 and 201701D221178; SCIENTIFIC AND TECHNOLOGICAL INNOVATION PROGRAMS OF HIGHER EDUCATION INSTITUTIONS IN SHANXI (STIP), grant numbers 2016117 and 2016118.

Acknowledgments: The research was supported by Scientific Instrument Center of Shanxi University, China.

Conflicts of Interest: The authors declare no conflict of interest. The funders had no role in the design of the study; in the collection, analyses, or interpretation of data; in the writing of the manuscript, or in the decision to publish the results.

\section{REFERENCES}

1. Croce V, Pianzzola MJ, Durand K, González-Arcos M, Jacques MA, Siri MI. Multilocus Sequence Typing reveals high variability among Clavibacter michiganensis subsp. michiganensis strains affecting tomato crops in Uruguay. Eur J Plant Pathol. 2016; 144: 1-13.

2. Zamora-Macorra EJ, Ochoa-Martínez DL, Valdovinos-Ponce G, et al. Simultaneous detection of Clavibacter michiganensis subsp. michiganensis, Pepino mosaic virus and Mexican papita viroid by non-radioactive molecular hybridization using a unique polyprobe. Eur J Plant Pathol. 2015; 143: 779-87.

3. Burger A, Gräfen I, Engemann J, et al. Identification of homologues to the pathogenicity factor Pat-1, a putative serine protease of Clavibacter michiganensis subsp. michiganensis. Microbiol Res. 2005; 160: 417-27.

4. Wassermann E, Montecchia MS, Correa OS, Damián V, Romero AM. Clavibacter michiganensis subsp. michiganensis strains virulence and genetic diversity. a first study in Argentina. Eur J Plant Pathol. 2017; 149: 35-42.

5. Soylu S, Baysal Ö, Soylu EM. Induction of disease resistance by the plant activator, acibenzolar-S-methyl (ASM), against bacterial canker (Clavibacter michiganensis subsp. michiganensis) in tomato seedlings. Plant Sci. 2003; 165: 1069-75.

6. Wittmann J, Brancato C, Berendzen KW, Dreiseikelmann B. Development of a tomato plant resistant to Clavibacter michiganensis using the endolysin gene of bacteriophage CMP1 as a transgene. Plant Pathol. 2016; 65: 496-502.

7. On A, Wong F, Ko Q, Tweddell RJ, Antoun H, Avis TJ. Antifungal effects of compost tea microorganisms on tomato pathogens. Biol Control. 2015; 80: 63-9.

8. Bocquet $\mathrm{L}$, Rivière $\mathrm{C}$, Dermont $\mathrm{C}$, et al. Antifungal activity of hop extracts and compounds against the wheat pathogen Zymoseptoria tritici. Ind Crop Prod. 2018; 122: 290-7.

9. Rashid TS, Awla HK, Sijam K. Antifungal effects of Rhus coriaria L. fruit extracts against tomato anthracnose caused by Colletotrichum acutatum. Ind Crop Prod. 2018; 113: 391-7.

10. Bayan Y. Chemical composition and antifungal activity of the plant extracts of Turkey Cardaria Draba (L.) Desv. Egypt J Biol Pest Co. 2016; 26: 579-81. 
11. Ahluwalia V, Sisodia R, Walia S, Sati OP, Kumar J, Kundu A. Chemical analysis of essential oils of Eupatorium adenophorum and their antimicrobial, antioxidant and phytotoxic properties. J Pest Sci. 2014; 87: 341-9.

12. Tapwal A, Nisha, Garg S, Gautam N, Kumar R. In vitro antifungal potency of plant extracts against five phytopathogens. Braz Arch Biol Techn. 2011; 54: 1093-8.

13. de Barros IB, de Souza Daniel JF, Pinto JP, Rezende MI, Braz Filho R, Ferreira DT. Phytochemical and antifungal activity of anthraquinones and root and leaf extracts of Coccoloba mollis on phytopathogens. Braz Arch Biol Techn. 2011; 54: 535-41.

14. Huang Y, Zhang P, He F, Zheng L, Wang YL, Wu JZ. Simultaneous determination of four bioactive flavonoids from Polygonum orientale L. in dog plasma by UPLC-ESI-MS/MS and application of the technique to pharmacokinetic studies. J Chromatogr B. 2014; 957: 96-104.

15. $\mathrm{Li} \mathrm{XL}, \mathrm{Li} \mathrm{YL}$, Zhang LJ. Isolation of the antifeeding components from Polygonum orientale and its effects on the digestive enzymes of Plutella xylostella larvae. Plant Prot. 2008; 34: 49-52.

16. Hu GF, Liu MY, Shen HM, Zhang XR, Li YQ, Niu SJ. A study on contact toxicity of extracts from Polygonum orientale against 13 species of agricultural pests. Acta Prataculturae Sin. 2011; 20: 229-35.

17. Elgndi MA, Filip S, Pavlić B, et al. Antioxidative and cytotoxic activity of essential oils and extracts of Satureja montana L., Coriandrum sativum L. and Ocimum basilicum L. obtained by supercritical fluid extraction. J Supercrit Fluid. 2017; 128: 128-37.

18. El Gendy AN, Leonardi M, Mugnaini L, et al. Chemical composition and antimicrobial activity of essential oil of wild and cultivated Origanum syriacum plants grown in Sinai, Egypt. Ind Crop Prod. 2015; 67: 201-7.

19. Wang L, Qiu P, Long XF, Zhang S, Zeng ZG, Tian YQ. Comparative analysis of chemical constituents, antimicrobial and antioxidant activities of ethylacetate extracts of Polygonum cuspidatum and its endophytic actinomycete, Streptomyces sp. A0916. Chin J Nat Med. 2016; 14: 117-23.

20. da Silva Hughes AF, de Lima FG, Lucchese AM, Neto AG, Uetanabaro APT. Antimicrobial activity of Syagrus coronata (Martius) beccari. Braz Arch Biol Techn. 2013; 56: 269-74.

21. Smânia A, Monache FD, Smânia EDFA, Cuneo RS. Antibacterial activity of steroidal compounds isolated from Ganoderma applanatum (Pers.) Pat. (Aphyllophoromycetideae) fruit body. Int J Med Mushrooms. 1999; 1: 325-30.

22. Wu LH, Yi HL, Zhang HF. Involvement of NO in sodium arsenite-induced yeast cell death. Acta Scien Circum. 2012; 32: 2612-6.

23. Netz DJA, de Freire Bastos MC, Sahl HG. Mode of action of the antimicrobial peptide aureocin A53 from Staphylococcus aureus. Appl and Environ Microb. 2002; 68: 5274-80.

24. Pushpanathan $M$, Gunasekaran $P$, Rajendhran J. Mechanisms of the antifungal action of marine metagenome-derived peptide, MMGP1, against Candida albicans. Plos one. 2013; 8: e69316.

25. Swift SR, Hart CA, Bartlett DW, Read ND. Interactions between azoxystrobin and Puccinia recondita, Erysiphe graminis, and Botrytis cinerea on the microscale. Scanning. 2001; 23: 153-4.

26. Li T, Yang SR, Chen M, Song LY, He CF. Antibacterial mechanism of ginger mix-fried magnolia bark extract against Escherichia coli and Staphylococcus aureus. Mod Food Sci Techn. 2016; 32: 84-92.

27. Li Z, Pan Q, Cui X, Duan C. Optimization on anthocyanins extraction from wine grape skins using orthogonal test design. Food Sci Biotechnol. 2010; 19: 1047-53.

28. Antony J. Taguchi or classical design of experiments: a perspective from a practitioner. Sensor Rev. 2006; 26: 227-30.

29. Sasikumar KSK, Arulshri KP, Selvakumar S. Optimization of constrained layer damping parameters in beam using taguchi method. Iran J Sci Technol Trans Mech Eng. 2017; 41: 243-50. 
30. López V, Akerreta S, Casanova E, García-Mina JM, Cavero RY, Calvo MI. In vitro antioxidant and anti-rhizopus activities of Lamiaceae herbal extracts. Plant Foods Hum Nutr. 2007; 62(4): 151-5.

31. Tian J, Ban X, Zeng H, He J, Chen Y, Wang Y. The mechanism of antifungal action of essential oil from dill (Anethum graveolens L.) on Aspergillus flavus. Plos One. 2012; 7: e30147.

32. Cathro P, McCarthy P, Hoffmann P, Zilm P. Isolation and identification of Enterococcus faecalis membrane proteins using membrane shaving, 1D SDS/PAGE, and mass spectrometry. FEBS Open Biol. 2016; 6: 586-93.

33. Qian L, Tao Y, Xie J. Antimicrobial mechanisms of tea polyphenol against Staphyloccocus aureus and Pseudomonas aeruginosa. Microbiol China. 2010; 37: 1628-33.

34. Zhang J, Feng J, Cai J, et al. Toxic effects of 1,4-dichlorobenzene on Chlorella pyrenoidosa: cell morphology antioxidant and system, and membrane permeability. Fresen Environ Bull. 2017; 26: 1932-9.

35. Jumaa M, Furkert FH, Müller BW. A new lipid emulsion formulation with high antimicrobial efficacy using chitosan. Eur J Pharm Biopharm. 2002; 53: 115-23.

36. Sikkema J, de Bont JAM, Poolman B. Mechanisms of membrane toxicity of hydrocarbons. Microbiol Mol Biol R. 1995; 59: 201-22.

37. Xing K, Chen XG, Liu CS, Cha DS, Park HJ. Oleoyl-chitosan nanoparticles inhibits Escherichia coli and Staphylococcus aureus by damaging the cell membrane and putative binding to extracellular or intracellular targets. Int J Food Microbiol. 2009; 132: 127-33.

38. Cheng KJ, Ingram JM, Costerton JW. Release of alkaline phosphatase from cells of Pseudomonas aeruginosa by manipulation of cation concentration and of $\mathrm{pH}$. J Bacteriol. 1970; 104: 748-53.

39. Turgis M, Han J, Caillet S, Lacroix M. Antimicrobial activity of mustard essential oil against Escherichia coli O157:H7 and Salmonella typhi. Food Control. 2009; 20: 1073-9.

40. Wink M, Ashour ML, El-Readi MZ. Secondary metabolites from plants inhibiting ABC transporters and reversing resistance of cancer cells and microbes to cytotoxic and antimicrobial agents. Front Microbiol. 2012; 3: 130. 